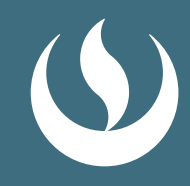

Javier Darío Restrepo

\title{
El futuro \\ del periodismo
}




\section{Javier Darío Restrepo}

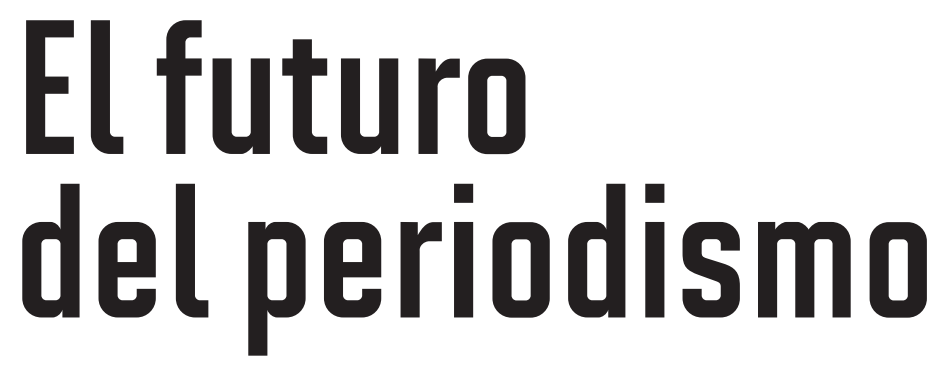

\section{Conferencia Magistral}

Setiembre de 2017

Universidad Peruana de Ciencias Aplicadas 
(C) Universidad Peruana de Ciencias Aplicadas (UPC)

Primera publicación: setiembre de 2017

Autor:

Javier Darío Restrepo

Editora:

Diana Félix

Correctora de estilo:

Isabel Domínguez

Diseño de cubierta:

Martha Rechkemmer

Diagramación:

Martha Rechkemmer

Fotografía de anteportada: Red Ética FNPI

Editor del proyecto editorial

Universidad Peruana de Ciencias Aplicadas S.A.C.

Av. Alonso de Molina 1611, Lima 33 (Perú)

Teléf: 313-3333

www.upc.edu.pe

Primera edición: setiembre de 2017

Libro digital disponible en: repositorioacademico.upc.edu.pe

\section{Universidad Peruana de Ciencias Aplicadas Centro de Información}

Restrepo, Javier Darío

El Futuro del Periodismo. Conferencia Magistral/ Javier Darío Restrepo. Primera edición.-Lima: Universidad Peruana de Ciencias Aplicadas, 2017

ISBN (PDF): 978-612-318-111-6

ISBN (EPUB): 978-612-318-112-3

Periodismo - Periodismo digital - Periodismo como profesión - Periodistas Periódicos - Aspectos sociales

DOI: http://dx.doi.org/10.19083/978-612-318-111-6

Todos los derechos reservados. Esta publicación no puede ser reproducida, ni en todo ni en parte, ni registrada en o transmitida por un sistema de recuperación de información, en ninguna forma ni por ningún medio sea mecánico, fotoquímico, electrónico, magnético, electroóptico, por fotocopia o cualquier otro, sin el permiso previo, por escrito, de la editorial.

El contenido de este libro es responsabilidad del autor y no refleja necesariamente la opinión de los editores. 
La Conferencia Magistral "El futuro del periodismo" se realizó gracias al trabajo conjunto de la Fundación Gustavo Mohme Llona y la Carrera de Comunicación y Periodismo de la Universidad Peruana de Ciencias Aplicadas (UPC).

Se convirtió en el insumo del taller "Reflexiones periodísticas: medios de comunicación, ética y fuentes de financiamiento" al cual fueron invitados periodistas de diversas regiones del país. 



\section{HOMBRE SABIO}

Habla con la seguridad de quien ha recorrido el exigente camino de un periodista que conoce claramente por qué hace lo que hace, y a quién le debe lealtad y respeto. Habla con el optimismo de quien examina los hechos desde lo público y de quien reconoce, en los problemas propios de la identidad profesional, una oportunidad para fortalecer el quehacer.

El Maestro Javier Darío Restrepo no levanta la voz, no maquilla las palabras, ni requiere edulcorarlas acompañándolas de adjetivos que nos distraen de los datos.

Con la sabiduría que lo caracteriza, reconoce una clara diferencia entre el sentido del tiempo y del espacio que imponen los sentidos, y el sentido del tiempo que nos exige el pensamiento. Por ello, como bien nos señalara durante su estancia en Lima en el último día de agosto pasado, resulta indispensable, por el bien de nuestras audiencias, "lograr que se sientan respetados en su inteligencia".

Javier Darío Restrepo, máximo referente en temas de ética periodística en América Latina, pasó nuevamente por la Facultad de Comunicaciones de nuestra Universidad para conversar con alumnos, profesores y periodistas, así como para recordarnos que hoy, más que nunca, debemos defender la verdad por sobre las instituciones; las caídas de circulación e ingresos con contenidos de calidad y 
de paga, así como fortalecer la independencia, atributo indispensable de la confianza periodística.

De Javier Darío son todas las ideas expuestas. De Javier Darío son las interrogantes que ha sembrado con elegancia entre quienes tuvimos la suerte de escucharlo y compartir dilemas.

Si algo tengo claro es que el futuro del periodismo estará a salvo mientras, como señalara Rafael Santos Calderón en el prólogo del libro Oficio de Equilibristas escrito por Germán Rey, los periodistas recuerden que "caminamos todos los días por una línea muy fina, pero en la medida en que haya más vocación, más oficio, más responsabilidad, será más fácil transitarla" (Santos Calderón, 2002:19).

Si algo tengo claro es que el futuro del periodismo, título de tu Conferencia Magistral que reproducimos en esta publicación, estará a salvo mientras las nuevas generaciones tengan el coraje de leerte una y otra vez; la voluntad de mantener vigentes y de defender las premisas del quehacer, así como la valentía de asumir lo que corresponda mientras ejercen la profesión.

Lima, setiembre de 2017 Úrsula Freundt-Thurne Decana de la Facultad de Comunicaciones Universidad Peruana de Ciencias Aplicadas 


\section{El futuro del periodismo}

Estamos aquí, ustedes y yo para comprobar si es cierto o no que el periodismo que hemos conocido tendrá que desaparecer y que será reemplazado por otra manera de hacer periodismo. No lo haremos con el tono apocalíptico de los notarios de desgracias, sino con el acento feliz de los exploradores de posibilidades.

Hay que abrir bien los ojos, despojarlos de las legañas del prejuicio, sin las anteojeras de los intereses personales para ver, en primer lugar, lo que está sucediendo en el mundo del periodismo y, después, las posibilidades que nos ofrece esta coyuntura que nos ha tocado vivir.

Sin más preámbulos vamos a los hechos que están sucediendo. Probablemente los conocemos aislados, desconectados los unos de los otros, pero no como un conjunto elocuente, como la visión de un amplio panorama desde el aire o con la ayuda de la cámara de un dron, que da la majestuosa perspectiva que abarcan los ojos de un águila en vuelo.

De ese conjunto hacen parte los siguientes hechos: 


\section{La caída de circulación de diarios impresos}

Ocurrida en los últimos años en Alemania, España, Inglaterra y Estados Unidos.

Entre el 2000 y el 2009 la circulación de los diarios en Estados Unidos cayó en un 25\%, según se lee en el estudio "Diez años que agitan el mundo de los medios" del Instituto Reuters.

Y en 2012 continuaba la caída, que en ese año fue del 0,7\% respecto de las cifras del año anterior. Los domingos la circulación bajó en 1,4\%.

En España, la caída de la circulación en los últimos 5 años fue en promedio del 18\%. El solo periódico El País, con su apreciable circulación internacional, entre el 2011 y el 2012 tuvo una caída del 10,1\%.

Por su parte, la Asociación de periódicos alemanes registró una caída del 17\% durante el período 2005-2012. Aún más estruendosa fue la caída del 40\% y el 50\% de algunos de los periódicos de calidad en el Reino Unido, según el citado informe del Instituto Reuters.

No son datos completos de lo que está sucediendo en el mundo, pero se trata de países significativos que, como Alemania, la economía más grande de Europa, o Estados Unidos donde la empresa periodística ha tenido sus más exitosas realizaciones, obligan a pensar que algo muy serio está pasando en la empresa periodística y en el periodismo mismo. Es una preocupación que aumenta ante el segundo hecho, ligado al anterior. 


\section{La caída de la publicidad}

Cuando el consultor español de medios, Juan Varela, escribió "la publicidad nunca volverá a estar en los medios como antes" tenía sus razones, no se trataba de alarmar, el suyo era solamente el registro frío de hechos como estos:

a. La caída de la circulación, que es imparable. Según este asesor se agrega la pérdida de la publicidad impresa a la caída o freno de la publicidad digital que, en su mayoría, llega a los diarios. Un caso patético fue el de la conocida revista Newsweek, de The Washington Post, vendida después de cuatro años de circulación decreciente y de pérdida del 79\% de su publicidad.

a. En esa crisis hubo un momento en que la editora Tina Brown llegó a pedir 82 portadas diferentes para un mismo tema, en un desesperado intento de dar con lo que podía atraer a los lectores. La angustia de Tina no ha sido única.

b.Según la Asociación de periódicos de Estados Unidos, los ingresos publicitarios de los diarios europeos cayeron $45 \%$ entre 2001 y 2012.

c. Algo parecido ha ocurrido en España. La crisis del diario El País le sirvió a la prensa española para comprobar que en los últimos cinco años los ingresos por publicidad de la prensa europea habían caído en un 53\% y que en ese periódico habían dejado de entrar 240 millones de euros, o sea un descenso del 18,3\% respecto del mismo periodo del año anterior.

Cito de nuevo a Varela quien ante realidades como estas, concluye que el gran problema planteado es el de desarrollar nuevos métodos de negocio, de crear valor añadido en los contenidos y otros más de los que hablaremos más adelante, después de contemplar otros hechos de la crisis. 


\section{Es quizás el más dramático: los despidos de periodistas}

Esa pesadilla, que una vez u otra amarga los días o las noches, la vivieron los periodistas alemanes. En 2013 el Berliner Zeitung despidió a 40 de sus 368 empleados; también hubo recortes de personal en Der Spiegel, mientras el sindicato alemán de periodistas clamaba "por la ola de despidos absolutamente desproporcionada".

Debió ser un momento difícil para El País la supresión de 139 de sus 460 puestos de trabajo en 2012 y el recorte del 13\% de su salario a 320 trabajadores. Prisa, la empresa editora del periódico, a su vez, tuvo que hacer despidos masivos en varias de sus empresas, según registró en España El Economista.

En Estados Unidos, informó el Instituto Reuters, el empleo en los periódicos bajó 17\%, una manera eufemística de hablar de despidos y de periodistas en la calle.

\section{El cierre de periódicos}

El mes de diciembre de 2012 estuvo lleno de malas noticias: cerró en Alemania el Financial Times Deutschland: lo aplastaron pérdidas por 250 millones de euros. Al mismo tiempo, El País vivía el momento más intenso de su crisis y Murdoch cerraba el Daily convertido en tableta un año antes, después de perder 30 millones de dólares.

Antes se había conocido la bancarrota del Chicago Tribune en Estados Unidos y en Francia la desaparición de la edición impresa del France Soir, junto con La Tribune, el diario financiero francés y el Frankfurter Rundschau alemán. Agreguen ustedes la venta del venerable The Washington Post y las dificultades de un gigante como el The New York Times para concluir que en este comienzo de siglo una crisis está sacudiendo a la prensa mundial. 


\section{La crisis}

Douglas Mc Cabe, consultor de medios de Enders Research de Londres, no lo duda: "la crisis de los periódicos se está dando en todos los países desarrollados del mundo occidental”. Desde el 2006, en un artículo que sonó premonitorio, The Economist sacudió a los periodistas al anunciar que "los periódicos son una especie en peligro de desaparición".

Y si alguien lo dudaba, debió sentir que se le movía el piso ante la noticia conocida a comienzos de agosto de 2013. Un empresario de internet, conocido por sus ventas masivas de libros a través de su empresa Amazon compró The Washington Post por 250 millones de dólares.

El hecho no sorprendió a los que habían conocido en 2009 el préstamo de 250 millones (la misma cifra de compra del Post) de Carlos Slim al The New York Times, con que el periódico sorteaba una crisis financiera. En agosto de 2013 este periódico se vio obligado a vender en muy malas condiciones su periódico The Boston Globe por 70 millones de dólares.

Estos son datos suficientemente significativos de una crisis que está en el origen de los cambios que la prensa mundial tendrá que afrontar en el futuro, no más allá del 2035.

En su origen está la tecnología digital que llegó para cambiarlo casi todo. "Internet está transformando casi todos los elementos del negocio del periodismo: acorta los ciclos informativos, erosiona las largamente confiables fuentes de negocio y permite varias clases de competencias, algunas con leves costos de cobertura de la información y otras sin ninguno". Los redactores y directivos de The Washington Post que aún no salían de su sorpresa, le escucharon estas palabras al nuevo dueño del periódico, Jeff Bezos.

Aún los más reacios a admitirlo tuvieron que rendirse ante 
la fuerza de los hechos: la estructura empresarial y de negocios de la actividad periodística tendrá que cambiar.

En la imperante cultura digital el texto impreso no tendrá la misma demanda. Un fenómeno que no tiene por qué sorprender porque se ha venido repitiendo en la historia de las comunicaciones. Los iluminados manuscritos que los monjes convertían en obras de arte, comenzaron a desaparecer cuando apareció la imprenta; la impresión de periódicos y libros, a su vez sufrió el impacto de la radio y la televisión; ¿por qué extrañarnos ante el impacto de la tecnología digital sobre los tradicionales productos impresos?

Une encuesta en los quioscos revelaría que hubo un punto de quiebre cuando comenzó a desaparecer la demanda de periódicos, en las gerencias de los medios se podrían comprobar cambios en la demanda de anuncios por palabras, mientras crecían los usuarios de internet. Este hecho lo registra el experto español, Gumersindo Lafuente. El subraya la afirmación: "los últimos 15 años de revolución digital han minado la esencia industrial y el modelo de negocios de los medios" (Lafuente, 2014:15).

\section{Cuando todo cambia}

Los medios y los periodistas que han tomado nota de estos cambios, que miden el impacto de la nueva condición del usuario de internet, que de ser solo receptor de información ha pasado a poseer un instrumento que le da la posibilidad de ser emisor, han tenido que notar:

a. Que las fuentes de información se han multiplicado hasta el punto de que nadie está dispuesto a pagar por la información;

b. Que internet ha cambiado el sentido del tiempo que parece desaparecer ante el carácter instantáneo de sus mensajes y noticias. A la gratuidad de su información se añade lo instantáneo. Dos ventajas palpables sobre la información tradicional. 
c. El formato tradicional del periódico, su ritmo de producción resulta lento y pesado frente a la agilidad y velocidad del modelo digital.

d. También se altera el sentido espacial que casi desaparece en internet, utilizable en cualquier lugar. El espacio es una limitación del medio impreso, sobre el que gravitan las limitaciones de los desplazamientos para la recolección de información y para la distribución del producto.

e. Además, los costos de producción, favorables para quien se acoge a la tecnología digital, ruinosos para quien insiste en la tecnología tradicional. Esta circunstancia se debe sumar a la otra: la disminución de los ingresos por publicidad y por circulación. Esa inferioridad de condiciones explica la urgencia de pensar y poner en marcha una nueva estructura económica. "Hay que construir de nuevo la estructura industrial del periodismo", concluye Lafuente (Lafuente, 2014:20).

Los medios están abocados a una búsqueda con urgencia de vida o muerte. Según Varela "no sabemos cómo serán los nuevos modelos de negocio, pero la experiencia ofrece algunas certezas: ser más flexibles y rápidos, mantener las fuentes de ingresos, crear valor añadido en los contenidos, generar servicios comerciales, y un largo etcétera" (Varela, 2014: 52).

Los diarios de Estados Unidos reaccionaron ante los primeros anuncios de la revolución que se fraguaba entre los avances de la tecnología digital y ya a comienzos de 2013 eran 400 los diarios que habían adoptado el pago digital para sus ediciones digitales. Todo un cambio de estrategias de circulación y de modelo de negocios mucho mayor que el mero crecimiento de las ediciones digitales de pago, explicó la Alianza de medios auditados.

Estos mecanismos de defensa activados en el mundo del periodismo, propiciaron la aparición de iniciativas que dejaron ver los 
perfiles de la nueva empresa periodística, pero además está apareciendo una conciencia clara de lo que significa la pérdida del monopolio de la intermediación. Son dos fenómenos que hoy mantienen al periodismo en estado de expectativa creadora.

Piensen nomás en la situación que se crea en un periódico que ha visto caer su circulación y su publicidad, que ha tenido que acudir al doloroso recurso del despido de personal, que ha visto como oscuras señales premonitorias el cierre de otros periódicos, o su desaparición en papel y su salto a la versión digital. Para muchos esta acumulación de signos negativos impone un regreso al cero original y a la necesidad de construir a la izquierda de ese cero. Es lo que lúcidamente reflexiona Lafuente: "puede parecer una paradoja, pero la crisis económica y estructural que está arruinando los medios y ha puesto en cuestión su independencia va a dar lugar a sistemas de financiación que la refuerzan" (Lafuente, 2014:18).

En efecto, no se trata de blindar y mantener vigoroso el negocio, sino de fortalecer e incrementar la independencia y la credibilidad, por tanto, cualquier cambio en la estructura económica de los medios deberá tener como mira la preservación de esa independencia y la eliminación de esos generadores de desconfianza que convierten a los medios en material prescindible.

En la crisis han contado como factores eficaces, la multiplicación de fuentes de información y la consiguiente pérdida del monopolio de los periodistas como fuentes privilegiadas de información. Cualquier usuario de internet puede ser fuente, los periodistas ciudadanos aparecen para satisfacer la necesidad de información instantánea, breve y, si es posible, excitante. El periodista tradicional y sus medios llegaron así a ser prescindibles, no solo por esa multitudinaria competencia, sino también porque siempre habían cargado con la sospecha de no ser independientes sino, subordinados a sus fuentes de financiación. 


\section{La estructura económica}

La crisis digital aparece, en consecuencia, como la oportunidad de buscar otra estructura que libere al periodismo de la sospecha de ser los escribanos del poder económico, o del poder político, o de los anunciantes. Y es este el sentido de esta búsqueda de una nueva estructura que haga desaparecer la vinculación del periodismo con el negocio y lo muestre, sin ninguna clase de sospechas, como un servicio público.

Retornando a las fuentes de la profesión, a la crisis estructural y económica de la profesión que ha puesto en cuestión su independencia, debe responderse con un sistema de financiación que refuerce y evidencie esa independencia.

Y a este objetivo contribuye una renovación de contenidos, que es el segundo gran componente de este cambio.

\section{Los contenidos}

Con fuertes razones se viene repitiendo la pregunta sobre la posibilidad de que sobreviva el periodismo que hemos conocido. Quienes así se lo plantean es posible que tengan en mente la permanencia de las técnicas y los modos de informar a que nos hemos acostumbrado y a todos ellos habría que decirles con franqueza que ese periodismo difícilmente sobrevivirá y que lo deseable es que no sobreviva.

- ¿Está a punto de extinguirse el periodismo? Umberto Eco es optimista y piensa que sí es posible su supervivencia si a los periódicos se les cambian los contenidos. "Habría que hacer un periódico que se convierta no solo en la crítica de la realidad cotidiana sino también en la crítica de la realidad virtual. Este es un posible futuro para un buen periodismo", le respondió a Juan Cruz de El País. También le preguntaron en setiembre de 2011 a Ignacio 
Ramonet, el director del prestigioso Le Monde Diplomatique.

- Está en peligro de extinción, respondió. El ecosistema está cambiando.

- El ecosistema anterior ha explotado, pero la historia de los medios demuestra que siempre hubo cambios importantes.

Quizás el miedo con que hoy se recibe esta noticia sea un signo de la necesidad de esos cambios porque indicaría que, apoltronados en un modo de hacer periodismo, no nos hemos dado cuenta de la necesidad de cambiar.

Cito de nuevo a Ramonet: "Quizás no haya habido en mucho tiempo tanta posibilidad como la que hoy tiene delante el sistema convencional".

Los que dicen que nada hay más viejo que el periódico de ayer, señalan uno de los cambios que la emergencia de internet ha puesto en evidencia. "La vieja estructura de la información está pensada desde la escasez y su oferta vinculada a la actualización y lo efímero. Es un producto que se agota en un tiempo de vida breve", apunta Varela (Varela, 2014: 46).

Anticipándose a una de las tácticas de mercadeo que hoy imperan, el periodista ha echado tradicionalmente mano del recurso de la rápida obsolescencia de su producto, para obligar al consumidor a solicitar su reposición. Los electrodomésticos como las noticias, están hechos para durar poco.

Dentro de ese propósito de dar contenidos de interés y calidad para cada usuario se necesitan contenidos relevantes para el público. Se pueden considerar relevantes los que dejan al receptor con la sensación de haber encontrado algo nuevo y duradero, es decir, un regalo para la inteligencia y no solo para la curiosidad y los sentidos. 
La gente, anota el experto, "quiere más y mejor información y contenidos de lo que más le interesa” (Varela, 2014:49).

Ramonet, por su parte, se pregunta, ¿qué le pide uno a la información, hoy? Y aporta la respuesta: "que sea fiable. Y plantea el dilema diario del periodista que debe resolver entre la información rápida que se resuelve en favor de lo inmediato, con el sacrificio de lo preciso y, por tanto, de la credibilidad". "Los periodistas, agrega, se limitan a lo más rápido porque saben que en la rapidez está en parte la captación de audiencias, pero el ciudadano quiere fiabilidad, algo que no garantizan los canales de información urgente, inmediata, constante".

El mismo Ramonet en su diálogo con el diario El País llamó la atención sobre otros dos requerimientos del lector de hoy: "Entre un informativo que da 10 noticias rápidas, con lenguaje de prisa y otro que da cinco que te dejan la sensación de conocer y entender el hecho, el lector prefiere este por la integralidad de la información", pero sobre todo porque se siente respetado.

Aún agrega Ramonet otro elemento cuando se plantea el hecho de la fragmentación de las informaciones que se reciben a través de las distintas fuentes y en distintas jornadas. Queda la sensación de que los lectores siempre están recibiendo los fragmentos de un vitral roto. Anota Ramonet: "tiene que haber un especialista que pueda hacer el trabajo de reunir el vitral". Un especialista de lo general. Es la misma idea que Kelly Mc Bride de Page One a través de su experiencia como periodista ha encontrado: "la información debe ser organizada en un sistema coherente. El periodismo más exitoso transforma la información bruta en una narrativa de autoridad".

Es lo que emerge dentro del torrente noticioso que abruma a los lectores de hoy que cuando buscan lo que puede responder a sus expectativas, encuentran que entre tanta información improvisada e incompleta, fragmentaria y superficial, hay una que se destaca porque da una 
clara visión del conjunto y una honda mirada a lo esencial de los hechos.

Cuando llego a este punto, y a pesar de la evidente autoridad de las fuentes en que me apoyo, me hago la pregunta que muy posiblemente está rondando por sus cabezas: ¿un periodismo de esta naturaleza, es posible? Y ¿atraerá y retendrá lectores?

Esta última pregunta que tendrá respuesta más adelante, plantea el tercer tema de cambio que urge la tecnología digital: la relación periódico-lectores, periodista-lector.

\section{La relación con el lector}

Si debe cambiar la estructura económica y deben ser otros los contenidos, es porque la economía y los contenidos en función del lector determinan un cambio de relación.

Digámoslo de una vez: la relación de los medios con el lector deberá ser otra cosa distinta de la actual relación medio-cliente.

El cambio en esa relación hará la diferencia entre una nueva vida periodística y la que había impuesto una larga tradición.

Presionados por su situación y mal aconsejados por su experiencia de negociantes, los gerentes de medios llegaron a creer que serían una ayuda las facilidades de la tecnología digital para medir las preferencias de los lectores, como en cualquier encuesta comercial, de modo que en vez de una agenda propia los medios adoptarían solo la que podría dar satisfacción al lector. Observa Julián Gallo, un periodista y profesor argentino: “la reunión de editores pasó a ser una interpretación de lo que, según los registros, se había leído o no se había tenido en cuenta" (Gallo, 2014: 63).

Los editores se concentraron en la información digital sobre el número de visitas apostando a monetizarlas en algún momento. 
"Pasó el tiempo y los ingresos apenas si superaron el 10\% de los ingresos publicitarios totales en diarios de Estados Unidos y Europa", apunta Daniel Dessein al final de un libro sobre Los Nuevos Desafíos del Periodismo (Dessein, 2014:159).

Quizás el error consiste en asimilar al lector de noticias a un consumidor de alimentos, de bebidas o de perfumes. Son lógicas diferentes. Señalaba Dessein: "un lector de papel significa entre $10 \mathrm{y}$ 30 euros más en ingresos publicitarios que el visitante digital".

La conclusión desoladora para los gerentes es que el público creado por la tecnología digital "no está dispuesto a pagar por las noticias".

La experiencia como consultor de medios del español Varela le permite responder a ese problema con sonoridad de profeta: "sin creación de audiencias nuevas merman las posibilidades".

El lector no es un simple cliente; en esta coyuntura se está revelando como un actor del proceso informativo.

Sus años de lucha para crear un diario digital, el Mediapart, le enseñaron a Edwy Plenel que "debiera ante todo recuperarse la confianza del público lector. En el nuevo ecosistema de la prensa se combinan el trabajo específico de los periodistas y el debate democrático del público, suscitando su interacción y su fructífera confrontación" (Plenel, 2012:5).

Esta interrelación engrandece y dignifica a la prensa, al contrario de lo que sienten los que lamentan el fin del monopolio de la emisión. "La información en red interrelaciona con lo local y lo global, con la sociedad, con los individuos y con los contextos", agrega Plenel (Plenel, 2012:10), quien indica con énfasis entusiasta y tiene razón porque su experiencia le ha revelado que ese nexo con los lectores que mantienen su fidelidad, es la base de la libertad de un periódico. 
Los cambios que la tecnología digital ha propiciado están mostrando esa realidad: esta fortalecida relación con el lector representa, vigorizándola, la libertad de la prensa.

Los que, convencidos de esta necesidad, están construyendo esa renovada relación con el lector, descubren que dentro del presupuesto para esa construcción se impone la desaparición de esa línea vertical entre medios y periodistas, y el lector. Ese lector que puede ser emisor no admite los aires de gran señor que solían rodear al periodista.

En cambio, la línea horizontal de los que se tratan de igual a igual, define de entrada esa relación. Y así como desapareció el monopolio de la información, concentrado en el periodista y se extendió a todos los usuarios de internet, ha comenzado a ser anacrónico ese aire de importancia personal, como de aspirantes a príncipes, de los periodistas.

Leo, escrito por Plenel, "que ya no es banalidad decir que una prensa realmente libre es la que está interrelacionada al mismo tiempo con todos sus lectores. El desafío es escapar a la homogeneidad de la masa anónima y construir un público consciente e implicado que comparte verbos comunes de rigor, libertad y democracia" (Plenel, 2012:10).

A esta construcción se llega después de hacerles frente a preguntas que han llegado a ser comunes en nuestro tiempo: ¿retener y multiplicar los lectores satisfaciendo sus caprichos? ¿ $\mathrm{O}$ valerse del poder de los medios para manipularlos en beneficio del negocio, o del grupo político, o del gobernante?

Es un problema no resuelto en nuestros medios el de decidir cuál es nuestro papel: ¿darle gusto a los lectores publicando lo que prefieren, lo que sea con tal de no perder la clientela? El citado Gallo se refiere al resultado de esa decisión de atender al capricho 
del lector: "remarca lo peor de sus preferencias por sobre lo mejor; la audiencia masiva prefiere lo breve, lo leído, lo deshumanizado". Y agrega, citando a Nicholas Carr: "prefieren lo sexual, lo criminal, lo escandaloso, lo que no tiene un antes ni un después" (Gallo, 2014:65).

Como se ve es demasiado alto el costo para mantener así una fidelidad. Se refiere a esto Plenel al mencionar "una búsqueda escandalosa y obscena de la mayor audiencia".

También es obscena la práctica de los medios y periodistas que se valen de su poder para manipular comercialmente, políticamente, ideológicamente. Aquella y estas prácticas acaban volviéndose contra los medios; en cambio, el medio que aporta, el que, terminada su información, hace que sus lectores se sientan mejores personas, más conscientes de lo que sucede, esos son los que generan esa fidelidad larga de sus lectores.

Este lector que no recibe trato de cliente sino de socio, ni de subordinado sino de igual, exige, toma parte mediante la expresión de sus acuerdos o desacuerdos, o con sus propuestas o comentarios. Es el lector que contribuye, que le da colectiva a la información, a la reflexión y al debate público. Se genera a sí mismo una ininterrumpida e interrelacionada asociación libre entre periodistas y lectores (Plenel, 2012:11).

Es una interrelación que hace posible la tecnología de los nuevos medios; con ella se define el perfil del nuevo periodismo que hoy comienza a ser.

\section{Aparece el nuevo periodismo}

Sé que muchos de ustedes, al escuchar esta larga descripción de las calidades del periodismo que vendrá, estarán creyendo que es teoría, sueño o ilusión idealista, lejana de lo real. Por eso creo necesario 
mencionarles, como invitación a la esperanza, que en el mundo ya están apareciendo medios y periodistas con estas características.

El más conocido de todos es el caso del diario digital The Huffington Post que en pocos años, valorizado por su éxito, fue vendido a otro propietario como demostración de que este nuevo periodismo también puede ser un buen negocio. Es un periodismo de análisis inteligente, bien informado y con un diseño atractivo que se ha convertido en una necesidad para quien quiera estar bien informado.

2012 fue un año de crisis para la circulación de los periódicos en Estados Unidos, pero también lo fue de crecimiento para la difusión digital y para los productos complementarios: suplementos, ediciones patrocinadas, ediciones zonales, etcétera, que lograron un aumento del 5\% de circulación en ese año. En el año siguiente las ediciones digitales de los diarios superaron el 19\% de la circulación total. ¿Cómo? 400 diarios habían adoptado el pago digital, un nuevo modelo de negocio. Este cambio de estrategias de circulación y de modelo de negocio no fue coyuntural. El cambio llegó para quedarse.

El editor de Daily Telegraph, Tony Gallagher, le explicó a Daniel Dessein, vicepresidente de Adepa (la asociación periodística argentina), que se trata de romper el círculo vicioso de caída de circulación, recorte de personal, pérdida de calidad, mediante el aumento de la calidad en los contenidos y de la credibilidad. Los usuarios están dispuestos a pagar por contenidos exclusivos como los que encuentran los suscriptores de The New York Times. Después del acceso gratuito a cierto número de notas, los lectores encuentran una barra de pago que, traspuesta, permite el acceso a una información exclusiva que, en adelante, ningún usuario quiere perder.

De este modo la industria periodística ha encontrado una fórmula que le permite cobrar a los lectores que están dispuestos a pagar por un contenido. (Dessein, 2014:162) 
Los muros de pago hacen parte de las iniciativas con que los medios responden a la necesidad de adoptar una nueva estructura económica.

La Folha de Sao Paulo instaló la suya en 2011 y hoy cuenta con 60000 suscriptores digitales; se le han sumado los grandes diarios de Brasil.

Otra iniciativa exitosa es la del diario digital francés Mediapart en donde se puede seguir el proceso de la crisis:

- despido de periodistas del diario Le Monde,

- decisión de seguir en la profesión a pesar de todo,

- examen realista de las nuevas condiciones,

- adopción de unos principios básicos para seguirla ejerciendo,

- rechazo de la publicidad y de los patrocinios como apoyos, como clave para preservar la independencia,

- voluntad de presentar una información de calidad y de estimular y mantener la interactividad con los lectores.

El apoyo y relación con 150 mil suscriptores revela que la suma de esas condiciones abre las puertas de una nueva etapa en la historia del periodismo.

Examino todas estas fórmulas y encuentro como elemento común la voluntad de mantener vigente un oficio de informar a la sociedad de acuerdo con normas que despojan al periodismo de todas las prácticas que como malezas lo han limitado y degradado.

\section{Lo viejo de lo nuevo}

Observen ustedes la exigencia de calidad y exclusividad que implica un tránsito desde el modelo noticia que se limitaba al aquí y ahora de los hechos, que de ser algo exclusivo del periodista pasó a ser 
posibilidad al alcance de cualquier persona con un computador, una tableta o un café internet a su disposición.

De una información así, pasar a la información exclusiva y de alta calidad, ha significado un salto cualitativo en el que el periodista debe afinar, como pocas veces lo había hecho antes, las artes de su oficio. Pero al tiempo que descubre que su oficio había sido ejercido a medias y sin exigencias de calidad, da con la clave del futuro de su profesión. En adelante su ambición será la de entregar una verdad lo más completa posible.

Llama la atención otra característica. Los medios, al revisar su estructura económica descubren que su dependencia de la publicidad y de los patrocinios les resta independencia y con ella ese valor de la credibilidad que hace parte de la calidad y exclusividad que los usuarios quieren ver y sentir en la nueva forma de hacer periodismo.

Es cuando resulta evidente que la única dependencia aceptable para este periodismo del futuro será la del suscriptor, o sea la del lector. De ahí la naturalidad con que se acepta la nueva relación con el lector, que entra de lleno a hacer parte del medio de comunicación, en donde entra a ocupar un puesto que nunca se le debió haber negado o mezquinado. El lector siempre debió hacer parte de los medios que como bien social son su lugar propio.

Cuanto acabo de mencionar es el ideal ético de la información periodística: compromiso con la verdad, independencia y responsabilidad con la sociedad.

Es lo que Plenel saluda como el renacer de todo cuanto hay de digno, grande y verdadero en el periodismo. Refiriéndose a la crisis de los medios exclama: "es una buena noticia, pues vemos al periodismo volver a su razón de ser, a su justo lugar" (Plenel, 2012: 9). 
Kelly Mac Bride, mencionada antes, expresa la misma idea: "internet ha transformado el horizonte del periodismo, pero no así su misión tradicional y sus valores".

Confirma estas ideas el informe de Reuters, aludido atrás, "las noticias fundamentalmente las siguen produciendo los medios tradicionales, es decir, los periódicos impresos. Pese a su relativa pérdida de estatura, continúa el informe, las empresas periodísticas seguirán jugando un papel crucial en el mundo". Corresponde, pues, al periodista de hoy demostrar que el periodismo sigue siendo necesario.

Si en algún momento la estructura comercial de los medios quiso asignarle al periodista el papel subalterno de productor de entretenimiento, la coyuntura creada por lo digital demuestra que si esa es su función, el periodismo debe desaparecer aplastado por el peso de las poderosas industrias del entretenimiento. Pero si el suyo es el papel de estimular el pensamiento mediante el conocimiento de la realidad y de sus posibilidades de cambio, esa es la vocación que le da dignidad y permanencia. "Es el momento para que los periodistas demuestren que son necesarios para la sociedad" afirmó Ramonet al diario El País.

La clave del futuro la está dando la tecnología digital, imprescindible para cualquier proyecto de progreso, pero esa clave está condicionada por los ideales éticos de la profesión que le dan consistencia y valor a la tecnología. Hay que demostrar y demostrarnos que somos necesarios. Y esta es una enorme ganancia respecto de lo que profesionalmente estábamos viviendo. Además, es cada vez más evidente que un nuevo periodismo es posible para una humanidad que crece en ambiciones. 

El taller "Reflexiones periodísticas: medios de comunicación, ética y fuentes de financiamiento" se llevó a cabo el 31 de agosto de 2017 y contó, además, con la participación del sociólogo Guillermo Nugent, los periodistas de investigación Edmundo Cruz y Gustavo Gorriti como comentaristas y Úrsula Freundt-Thurne, Decana de la Facultad de Comunicaciones, como moderadora. Se agradecen sus valiosas ideas y compromiso con el periodismo.

Punto Seguido, la revista de los alumnos de la Carrera de Comunicación y Periodismo de la Universidad Peruana de Ciencias Aplicadas (UPC) realizó la cobertura de la Conferencia Magistral y una ronda de entrevistas a los participantes y periodistas peruanos que asistieron al evento.

Para acceder al material audiovisual ingresar a los siguientes enlaces virtuales:

Taller "Reflexiones periodísticas: medios de comunicación, ética y fuentes de financiamiento". Conferencia Magistral de Javier Darío Restrepo. Cobertura de Punto Seguido.

http://bit.ly/2xljRQC

Entrevista a Javier Darío Restrepo por Punto Seguido.

http://bit.ly/2xyIdbF

Entrevista a Guillermo Nugent por Punto Seguido.

http://bit.ly/2wK7snc 



\section{Presentación de}

Javier Darío Restrepo para el taller "Reflexiones periodísticas: medios de comunicación, ética y fuentes de financiamiento"

Lima, setiembre de 2017 



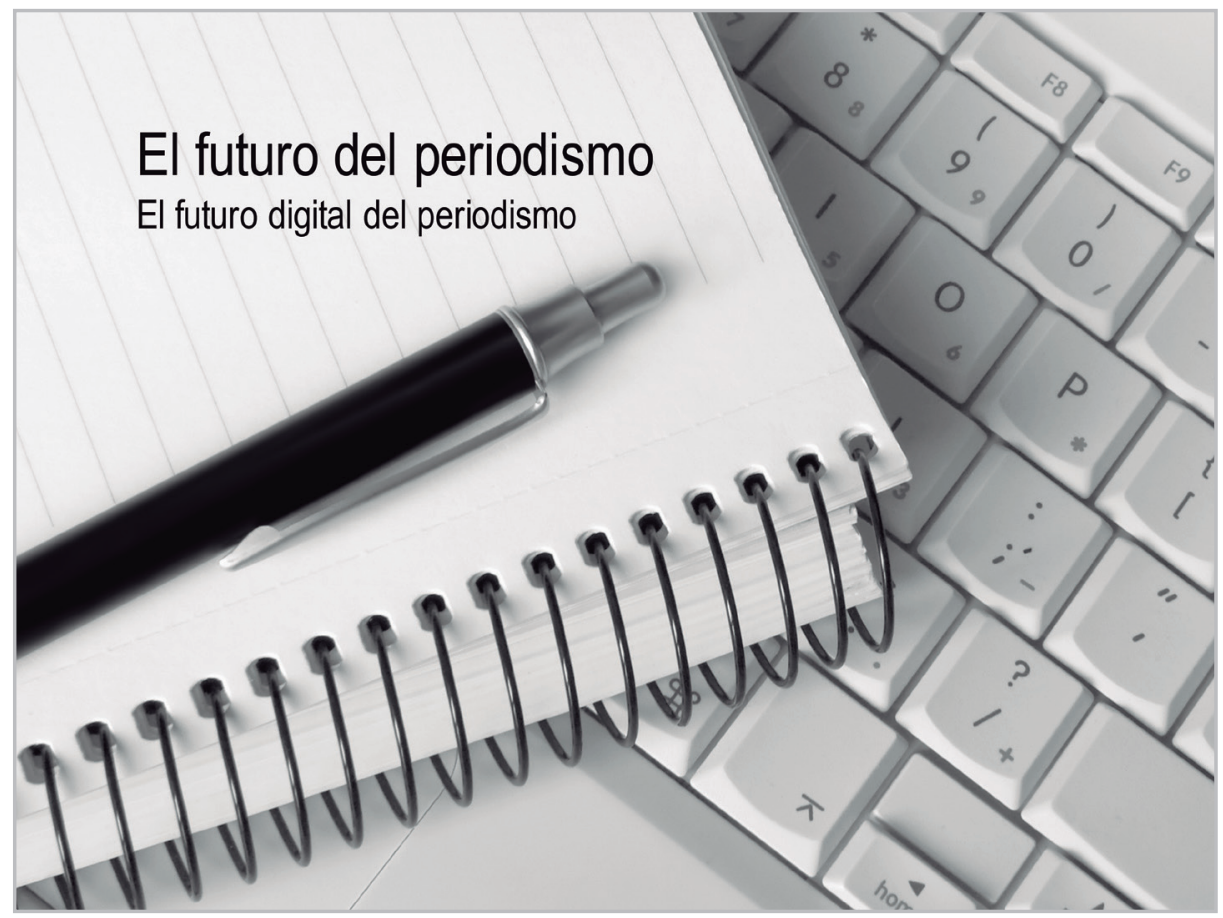




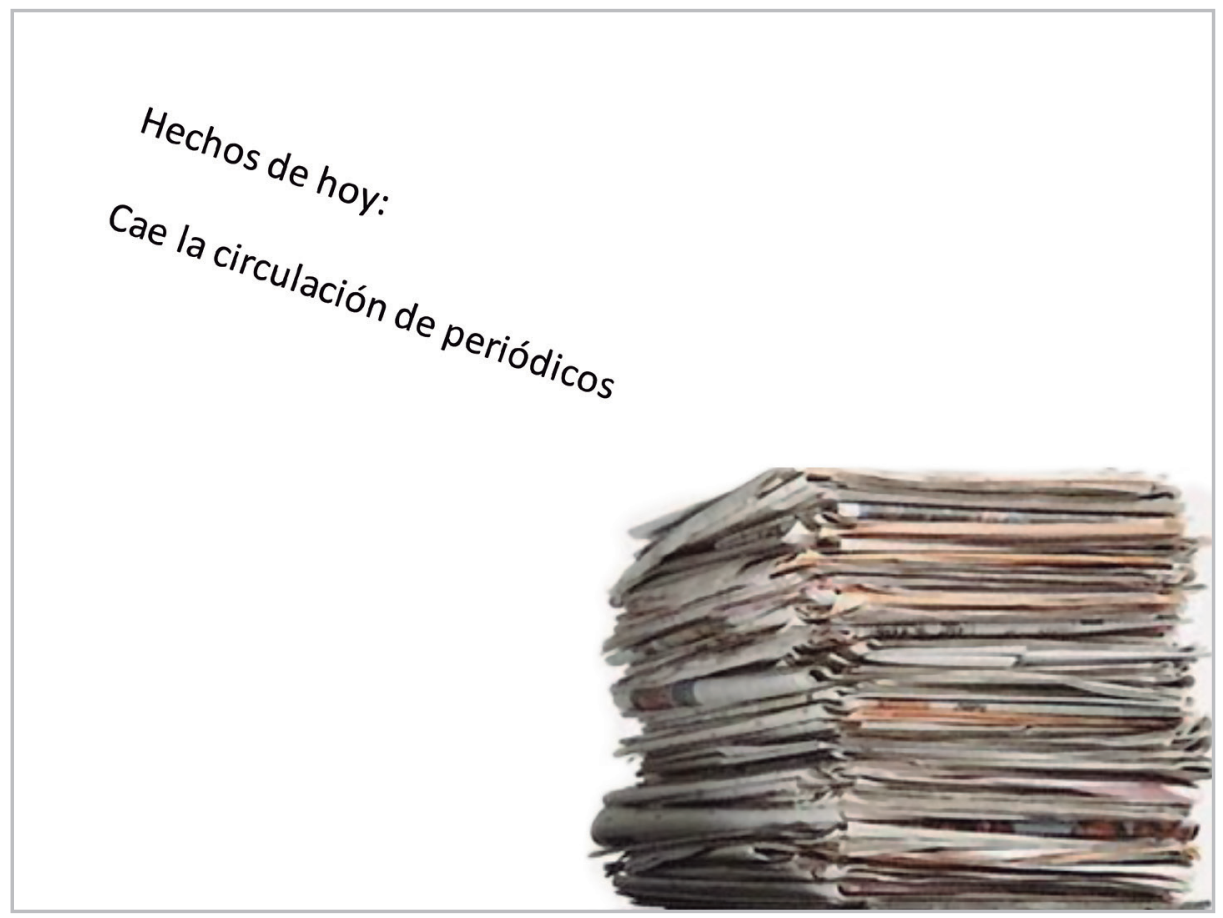




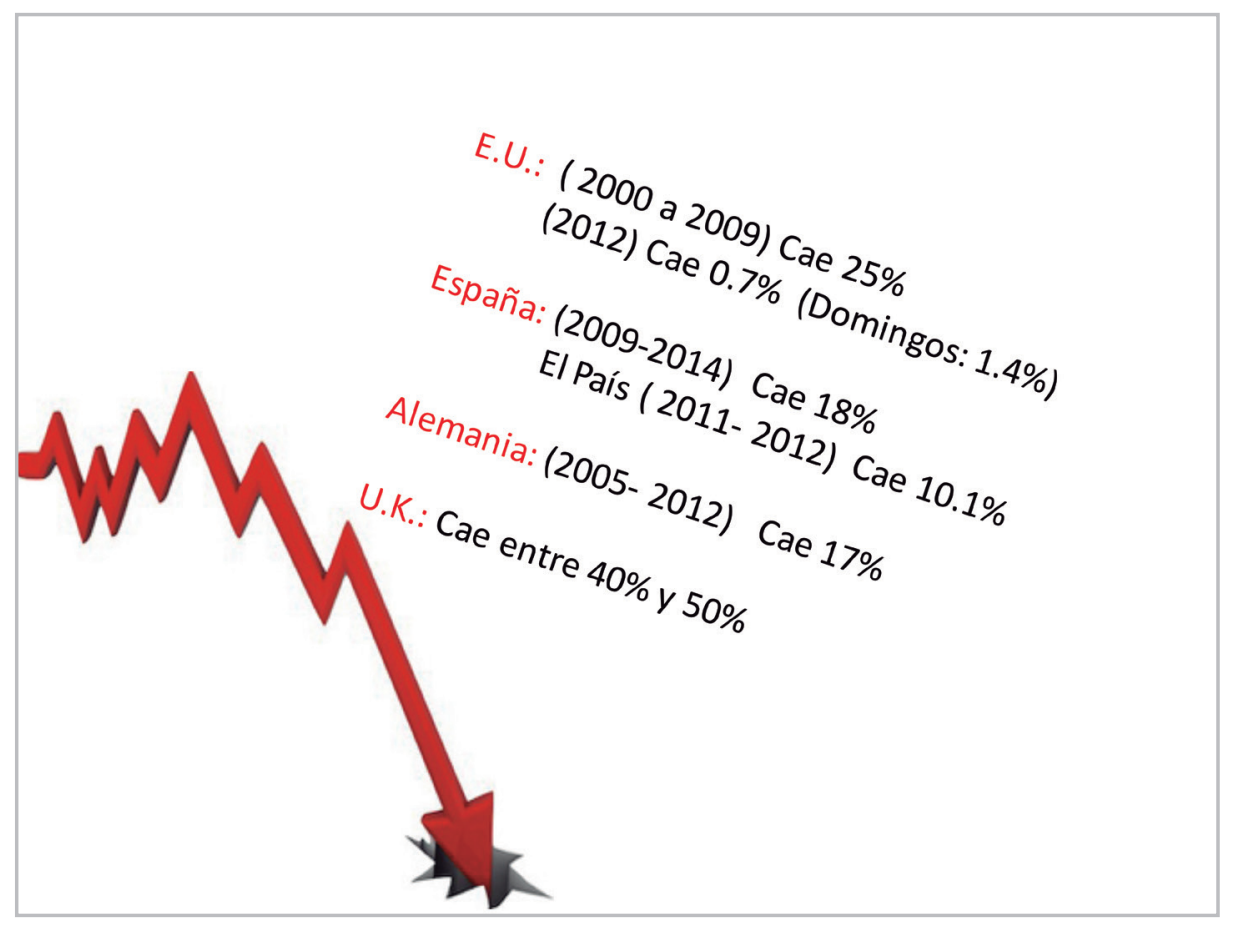




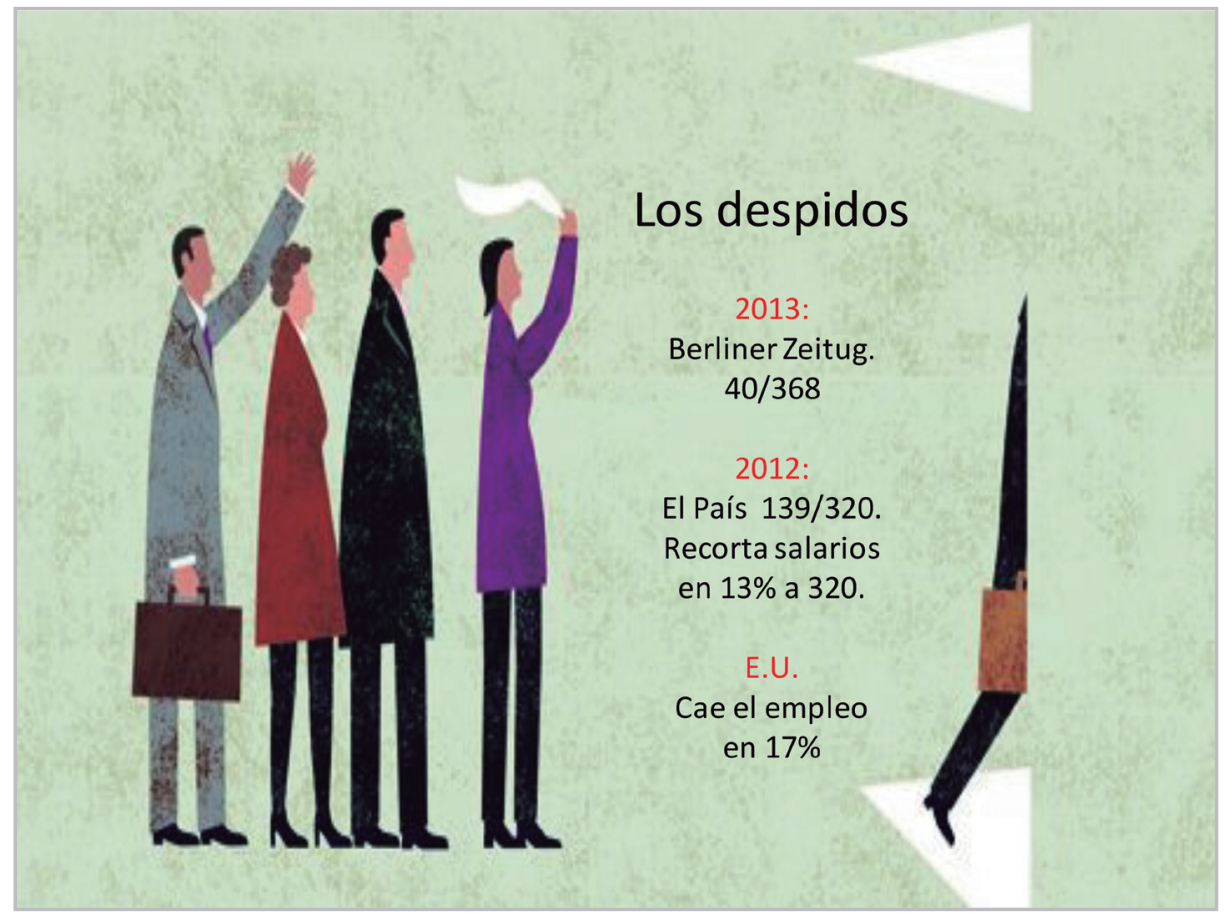




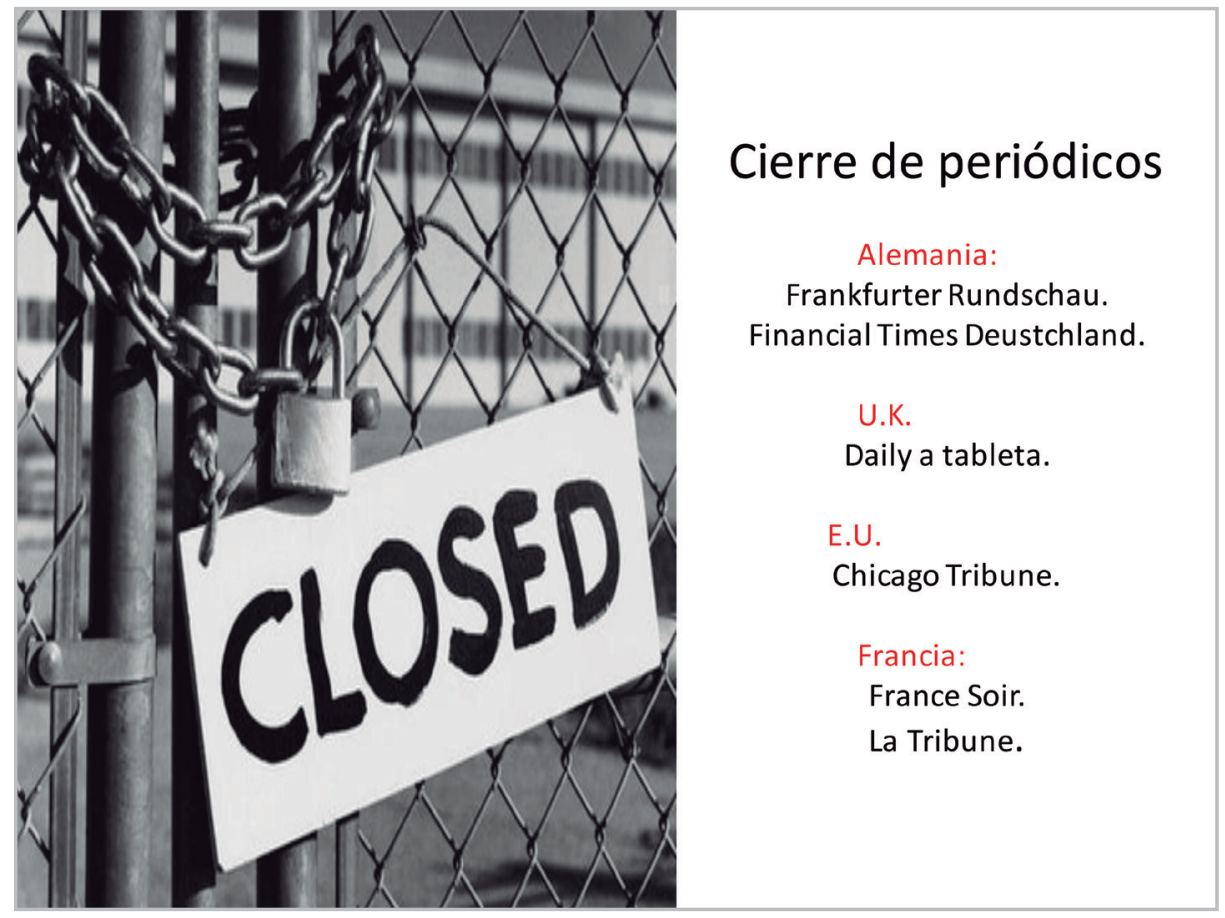




\section{Otros hechos}

\section{The $7 \mathfrak{s}$ aston $\mathbb{G}$ lobe}

Vende Boston Globe por 70"US

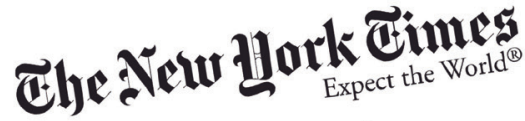

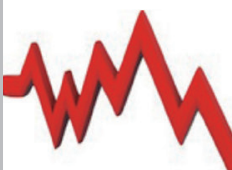

$\lim _{t}$

N. Y. T. $-(2009)$
préstamo de $250^{\prime \prime}$ us.

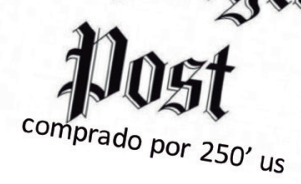




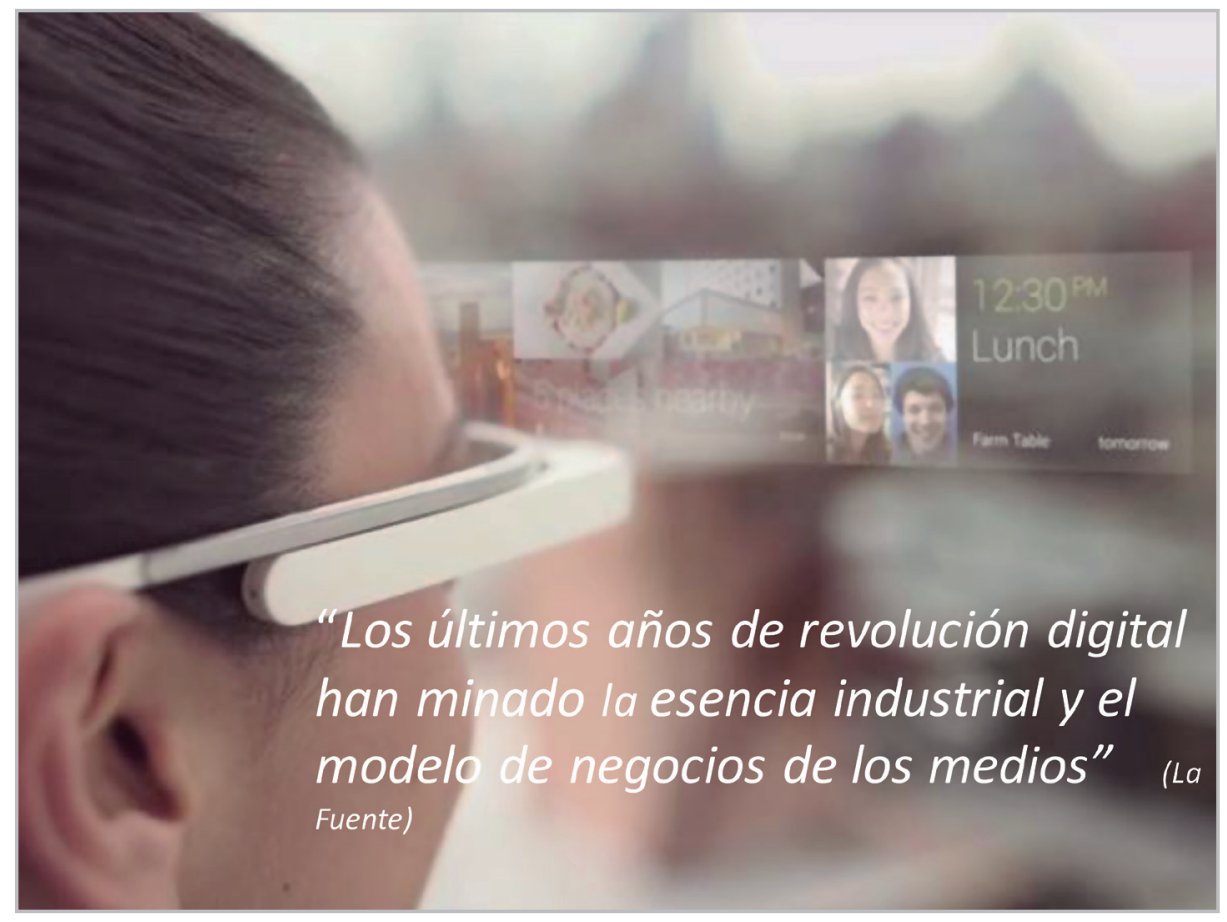




\section{Factores de cambio}

- Nadie quiere pagar por la información.

- Internet cambia nociones de tiempo y espacio.

- Formato tradicional aparece lento y pesado.

-Internet libera del espacio.

-Internet baja costos.

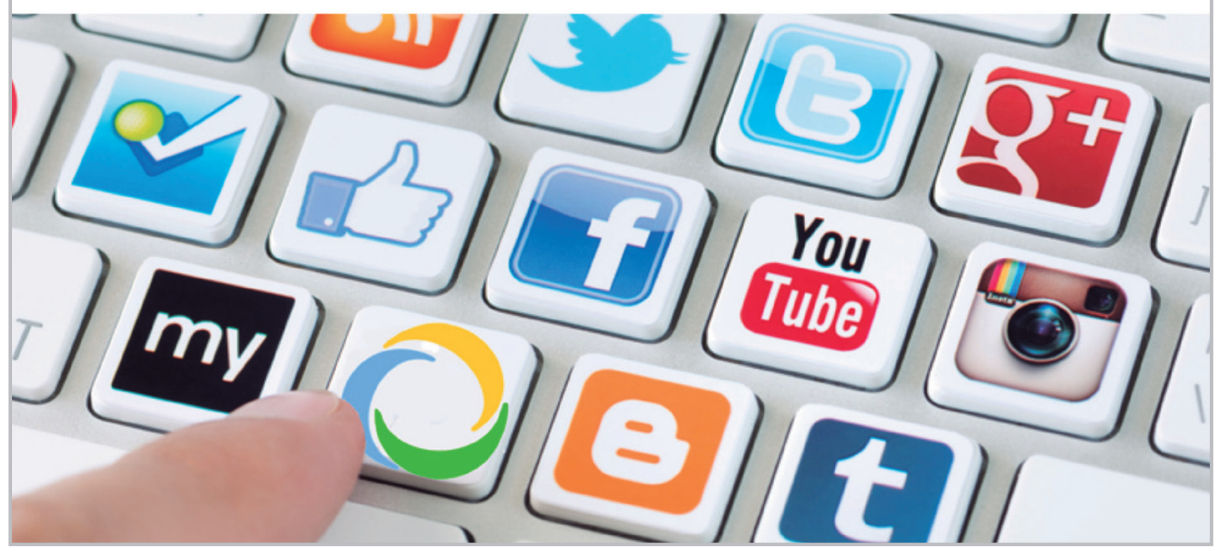




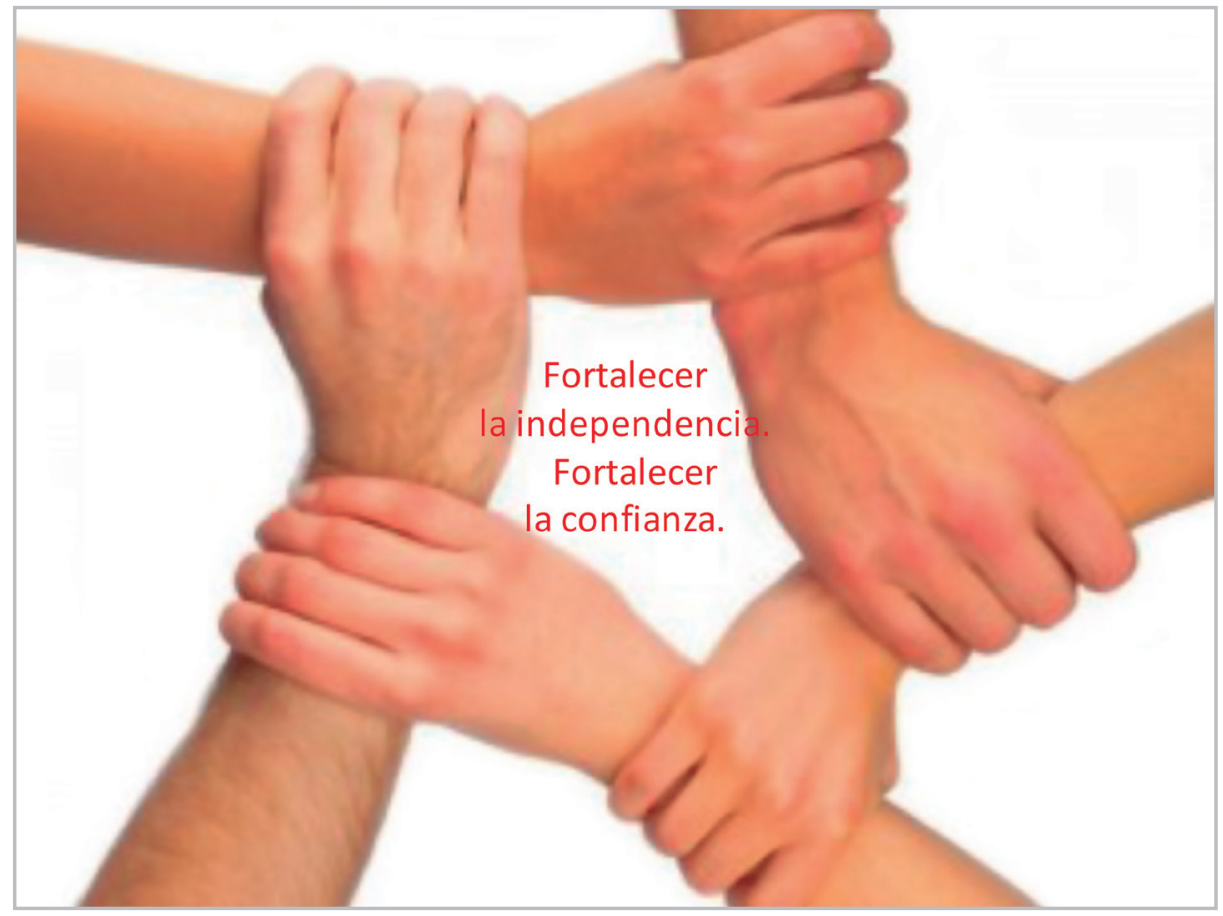




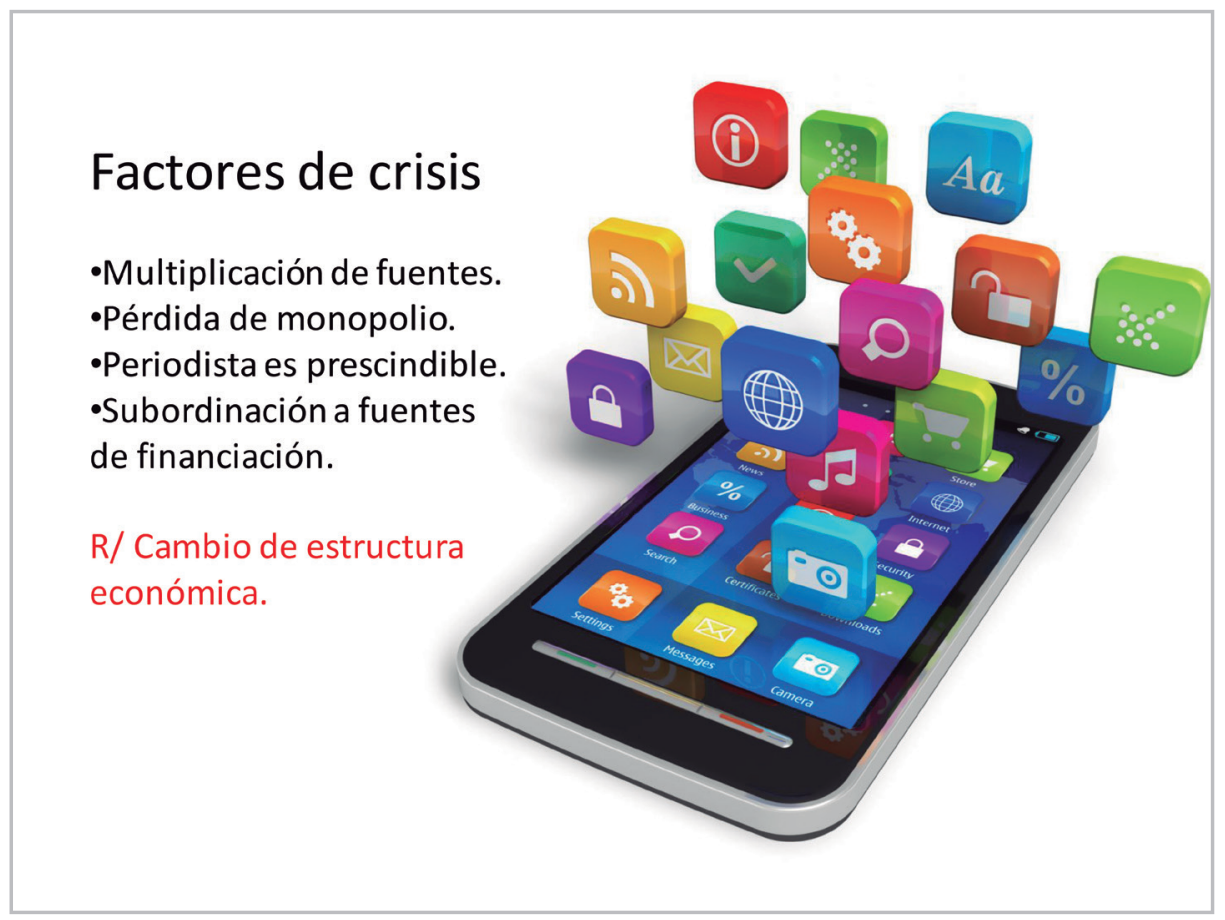


R/.- Cambio de contenidos.

-Más interés y calidad.

-Relevantes.

-Fiables.

-Integrales.

- Organizados.

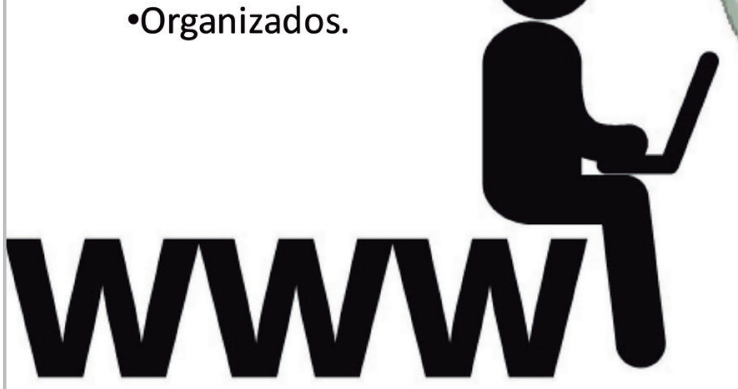




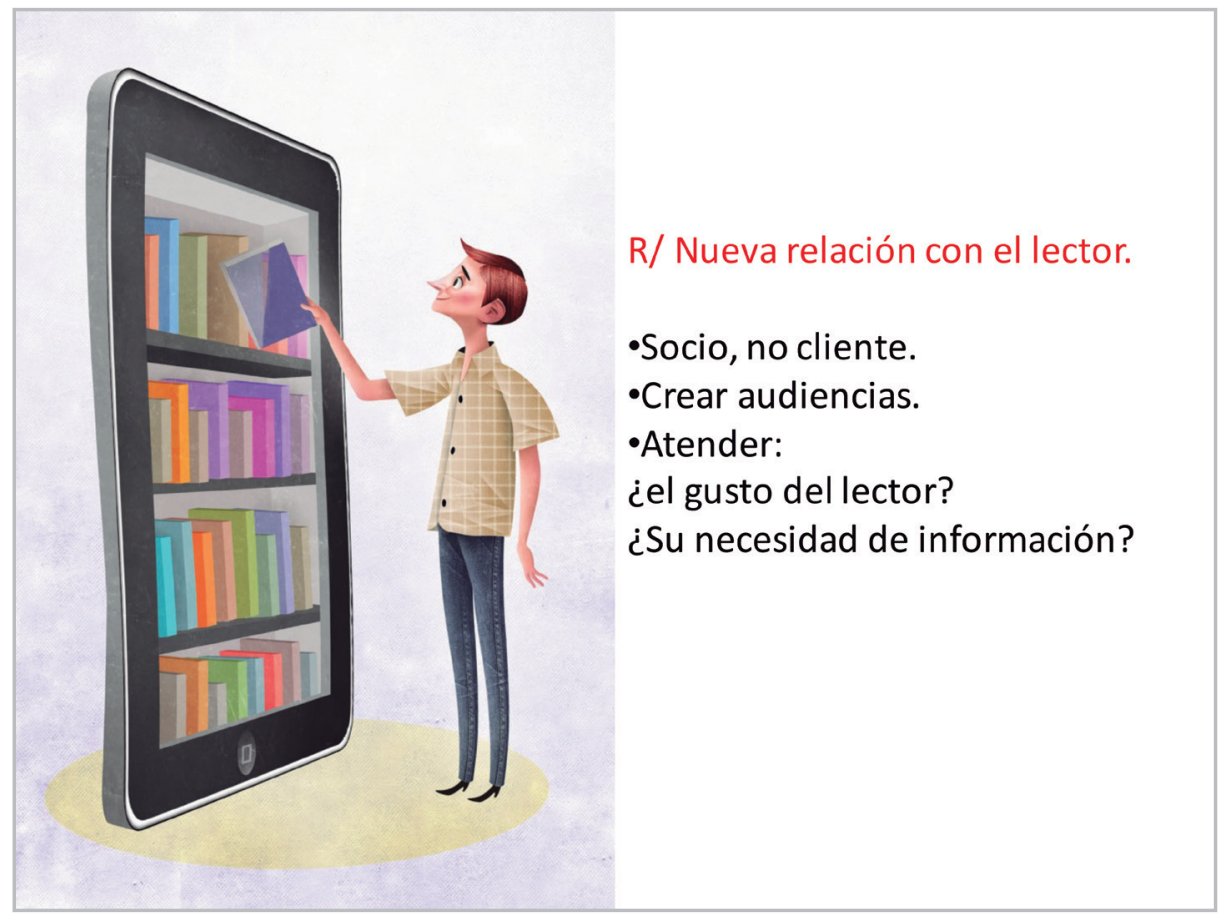




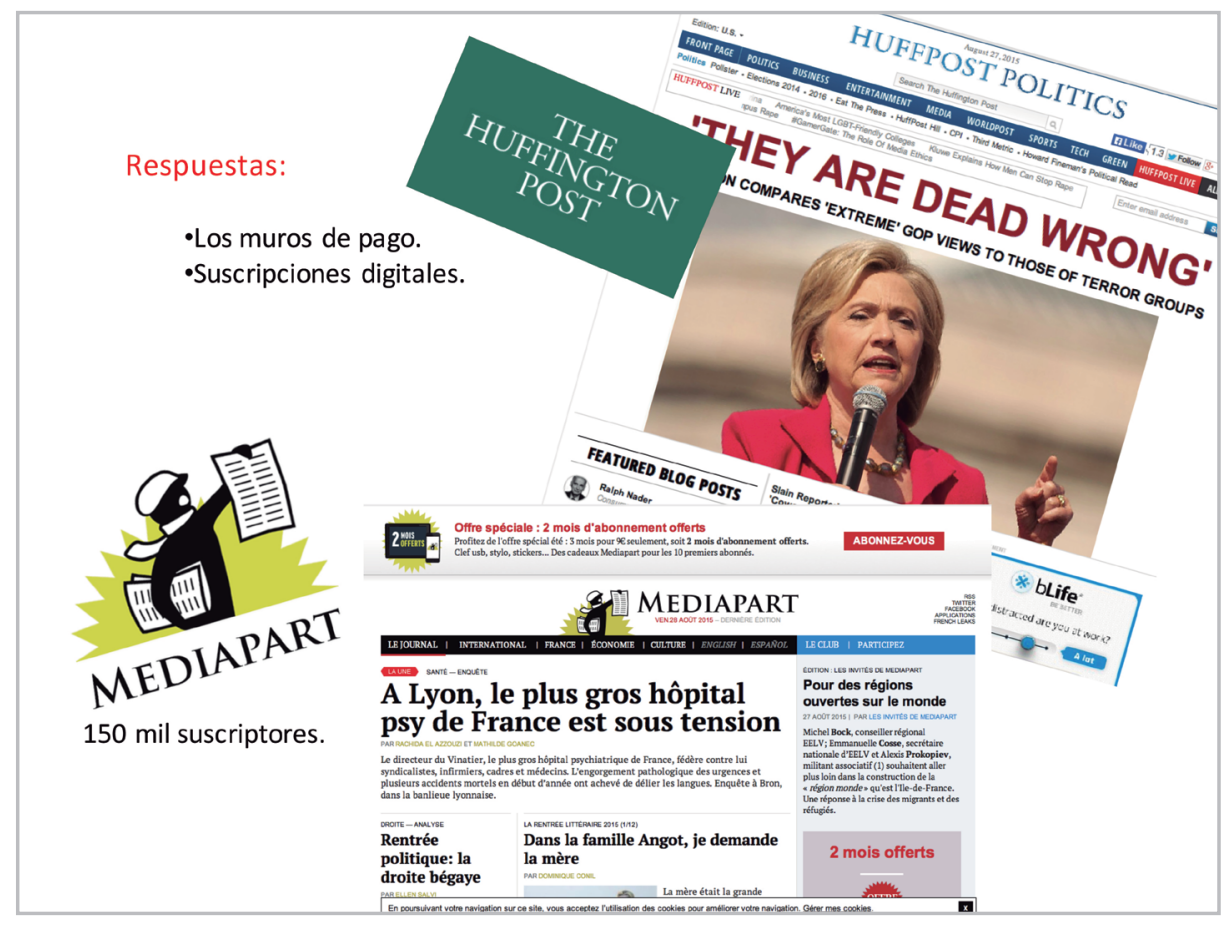




\section{La transición}

- De noticia a material exclusivo.

- De dependencia de publicidad a suscriptores.

- De lector cliente a lector socio.

- De entretenimiento a estímulo del pensamiento.

-Más necesario que el pan.

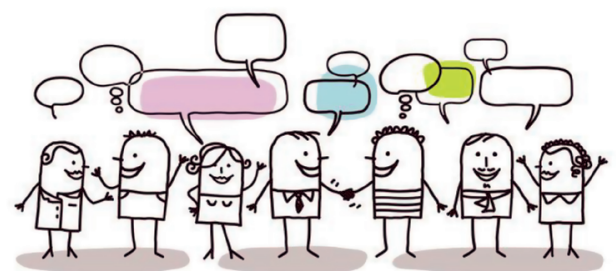

"Renace lo digno, grande y verdadero en el periodismo" Plenel 


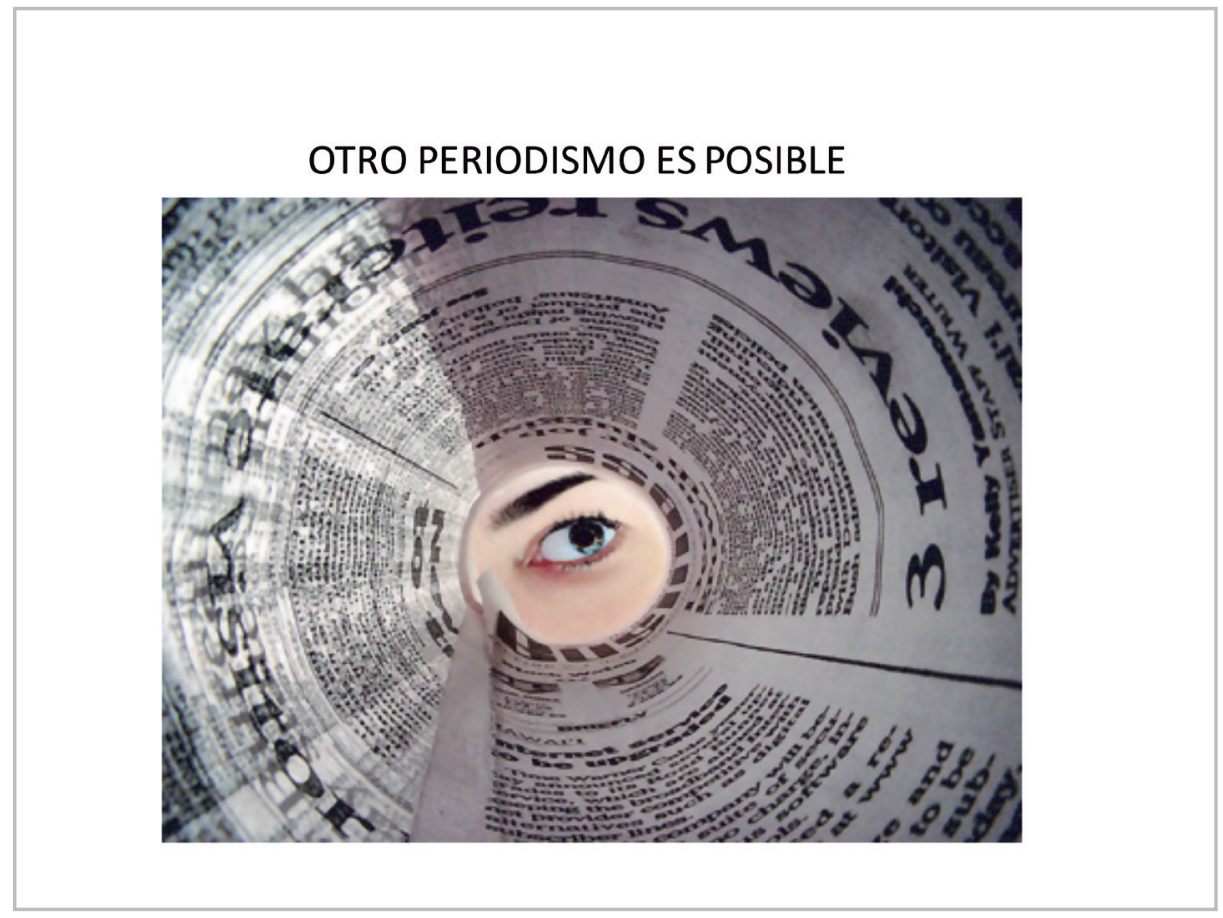




\section{Referencias}

LAFUENTE, G. (2014). ¿Habrá medios en 2030? En: D. Dessein y G. Roitberg (comps.) Nuevos Desafíos del periodismo. Buenos Aires: Ariel Adepa.

VARELA, J. (2014). El fin de la exclusividad. En: D. Dessein y G. Roitberg (comps.) Nuevos Desafíos del periodismo. Buenos Aires: Ariel Adepa.

GALLO, J. (2014) La droga de la audiencia. En: D. Dessein y G. Roitberg (comps.) Nuevos Desafíos del periodismo. Buenos Aires: Ariel Adepa.

DESSEIN, D. (2014) Confianza. En: D. Dessein y G. Roitberg (comps.) Nuevos Desafíos del periodismo. Buenos Aires: Ariel Adepa.

RAMONET, I. El País, Madrid, 11 de septiembre de 2011.

MARTÍN, J. (15 de octubre de 2012) La relevancia de los periódicos en la red. El País, Madrid. Reproducido por El Espectador, Bogotá.

PLENEL, E. (2012) Manifiesto-Combate. Reproducido en Bogotá por Complexus. Le droit de savoir.. París: Don Quichote editions.

LA ROTTA, S. Días de Prensa. El Espectador. 7 de agosto de 2013. pp. 24-25

POSADA CARBÓ, D. El futuro del periodismo. El Tiempo. 17 de febrero de 2012. p. 21

WIESSMANN, G. Agence France-Presse, AFP. 7 de diciembre de 2012 Tormenta Periodística. El Tiempo. 5 de diciembre de 2012 


\section{Recientes publicaciones de la Editorial UPC}

\section{7}

Cáceres Álvarez, Luis

La Catedral del Criollismo, Guardia Vieja del siglo XXI

Calero, Joel

La última tarde. Guion cinematográfico

Galagarza, Brenda y Seclén, Eloy

La primera cita. Guía para el registro de referencias y citación en textos académicos

Editorial UPC

Manual de estilo de la Editorial UPC

Loyola Angeles, Fernando

Diseña tu carrera. Unaguía para aprovechar las oportunidades del mercado laboral

Luna García, Rosa y Monteagudo Medina, MaryAnn

Diccionario para profesionales de la traducción. Terminología básica que todo traductor debe aprender

Chu Rubio, Manuel

Mis finanzas personales. Tercera edición

Sánchez Benavides, Oscar (comp.)

La inevitable globalización. Enfoque cultural y económico del escenario mundial 
Mangelinckx, Jérôme

Lucha contra las drogas en el Perú: una batalla perdida

Biondi Shaw, Juan y Zapata Saldaña, Eduardo

Nómades electronales. Lo que dicen las escrituras de los jóvenes: había que echarse a andar nuevamente

Merino Amand, Francisco

Ética para la función pública. De la indiferencia al reconocimiento

Visite la página de Facebook Editorial UPC: www.facebook.com/editorialupc

Encuentra nuestros libros en versión impresa en

librerías locales y nacionales de Perú.

Visita nuestra página web para adquirir

y contactar a la editorial:

editorial.upc.edu.pe 

